\title{
Internal Images: John Donne and the English Iconoclast Controversy $^{1}$
}

\section{DAVID K. ANDERSON}

Résumé : Au moment où John Donne écrivait ses poèmes dévots, l'église anglaise était de nouveau aux prises avec la question des images religieuses. Bien que le poète soit mort avant l'essor de l'iconoclasme pendant la Guerre Civile, il tenait compte du problème, non seulement dans ses Sermons, mais aussi dans sa poésie. La position de Donne était celle d'un calviniste modéré : il admet la valeur de l'imagerie divine tout en se rendant compte de son danger. Finalement, ses poèmes rendent les images religieuses privées, en les situant à l'intérieur de l'individu plutôt que dans l'église.

$\mathrm{W}$

hile John Donne was writing his devotional poetry in the first two decades of the seventeenth century, the English church was nearing the end of the largely peaceful consensus it had enjoyed during the reigns of Elizabeth and James. When Charles I succeeded his father in 1625 - overtly championing a high church agenda — what had been a discontented minority became the vanguard of a revolution famous in history for (among other things) its attack on divine imagery. For the second time in English history, church statuary and stained glass were shattered and wall frescoes were covered in whitewash. Though Donne did not live to see the rampant iconoclasm of the Civil War, the issue was one that had divided English Protestants since Cramner. Like any Englishman of his day, Donne was very much aware of the debate over imagery, and I believe that he articulated a firm position on it in his verse.

Unlike George Herbert or Henry Vaughan, Donne never writes explicitly about liturgy, ceremony or church decor in his poetry. He never wrote a poem called "Holy Communion" (as both those poets did) to contemplate the mystery of the Eucharist. What he does do repeatedly, though, is 
contemplate occasions like the Passion - the event that the Eucharist represents. Doing so necessarily raises questions of seeing and of imagery. In this essay, I wish to interrogate a range of Donne's religious poetry, spanning much of his career, to discern his attitude towards iconoclasm. First, I will discuss the problem of divine imagery in the period and Donne's attitude toward it. Then, turning to the divine poems, I will describe what I see as his solution. I will argue that Donne admits the power and importance of holy images as spiritual and intellectual aids, which, as John Phillips writes in The Reformation of Images, "bridge the gap between sense and spirit." 2 However, I will also show that Donne's poems consistently eschew physical, public icons, preferring to locate images mentally, within the individual, rather than in an actual church. In the final analysis, I believe that this position, which values the icon yet transfers it to the domain of private experience, shows Donne advocating a moderate Calvinist outlook between the two extremes associated with the "idolatrous" Laudians and the "irreverent" Puritans. The image's value in fortifying the believer through visual representation is shifted in the poetry from the public sphere to the personal, where it is unable to provoke collective idolatrous devotion but remains present to edify the individual Christian.

It is important not to oversimplify: Donne's stance on religious imagery does not represent his total religious perspective. All the same, that stance is important proof that Donne's poetry is doctrinaire from neither the Arminian nor the Puritan extremist perspective. Consider one of Donne's earliest poems, written during the time of his conversion to Protestantism in the 1590s. One might suppose that ardour for his new faith, or feelings of guilt or lingering attachment for his old, might colour Satire 3 ("Kind pity chokes my spleen"), ${ }^{3}$ wherein Donne surveys Europe's confessional possibilities, considering, among other things, the question of religious imagery. Instead, we have a young man's scathing castigation of the blindly orthodox: anyone who would follow such religious leaders as "a Philip, or a Gregory, / A Harry, or a Martin" (96-97) is asked, "Is this not excuse for mere contraries, / Equally strong?" (98-99). ${ }^{4}$

The speaker considers five fictional men who all attempt to "Seek true religion" (43), like young suitors searching for brides. For my purposes, however, the examination of Mirreus and Crants, who are drawn to the Catholic and Puritan creeds respectively, are the most important, for the question of iconography is key to understanding both. Mirreus looks for his intended in Rome because "He loves her rags so" (47), while Crants 
... loves her only, who at Geneva is called

Religion, plain, simple, sullen, young,

Contemptuous, yet unhandsome. (50-52)

The rags that Mirreus is attracted to are an unflattering metaphor for Catholic iconography. However, the appearance of Crants's "unhandsome" beloved, who represents the unadorned Reformed church, is no paragon of simple, unembellished beauty; rather she is severe and repellent. The poet despairs of the available alternatives. He encourages scepticism, reasoning that "To adore, or scorn an image, or protest, / May all be bad; doubt wisely" (86-87), a statement which causes Ernest Gilman to comment that Donne's own attitude toward church imagery "seems to move doubtfully between adoration and scorn." 5 Yet the poem is less an expression of indecision than of contempt for both sides. Donne's outlook on both parties in the dispute over imagery is gentler in his later works, seeing the merits of each rather than the flaws, but Satire 3 sets up an important paradigm of aversion to both extremes.

Though it is my intention to argue that Donne was a moderate Christian in early seventeenth-century terms, I disagree with critics who assume this makes him a high-church Anglican. Rather, I find that Donne occupies the wide middle-ground, as what Kenneth Fincham terms a "conformist Calvinist." Fincham divides English Protestants into four main groups: "radical Puritans, moderate Puritans, conformist Calvinists and anti-Calvinists." Conformist Calvinists, he states, were those who reconciled the Calvinist teachings on grace, the sacraments and ornament with the general direction of the Elizabethan and Jacobean church. ${ }^{6}$ I believe that this is the position affirmed by Donne's poetry. Such an analysis flies in the face of the commonly held opinion on Donne's religious identity, which, in Theresa DiPasquale's words, sees him as an "Arminian priest, aligned theologically with Andrewes and Laud" - an alignment that casts him as an iconophile. DiPasquale goes on to note, though, that " $[\mathrm{t}]$ his conception of Donne has ... been strongly challenged by recent scholarship."7

One of the central challengers is Daniel Doerksen. In "Preaching Pastor Versus Custodian of Order: Donne, Andrewes and the Jacobean Church," Doerksen attempts to redefine Donne as one who "identified with the

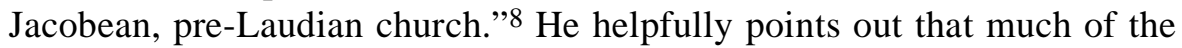
problem in correctly recognising Donne's stance is due, in part, to an archaic equation between Calvinists and radical Puritans:

Donne's moderate Calvinism has not been much recognised because he is such an original writer, and because Calvinism has often in the past been erroneously equated with Presbyterianism and with predestinarian extremes. Donne definitely 
opposed both of the latter, but fully accepted the predestinarian position of the Thirty-Nine Articles. ${ }^{9}$

Doerksen's article deals largely with Donne and Andrewes's opposing ideas about the role of the priest and argues, "For Donne and most of his Calvinist fellow churchmen, the minister was a preacher who also administered the sacraments." 10 Though Doerksen is specifically concerned with the role of the clergy rather than with church ornamentation, the two issues are certainly intertwined. Protestant theologians emphasised the written and spoken Word - publicly manifested in preaching - even as they diminished what we might call the "visual evangelism" of church iconography. It is a position, Gene Veith argues, that Donne supports:

Donne interestingly summarises the Reformation preference for the aural over the visual, when he observes that "the eye is the devil's door. But the ear is the Holy Ghost's first door." Lust and envy enter the soul through the eyes, and one can sin through the other senses, but it is through the ear, through the hearing of God's Word, that the Holy Ghost enters. ${ }^{11}$

Though I will argue that Donne recognises, in his poetry and his private life, the benefit of the visual, it is vital to understand his thoroughly Protestant distrust of physical images.

Donne certainly never approached the Arminians in their outright iconophilia. When Laud, for example, was impeached by Parliament in 1640, "[o]ne of the main charges against him, pressed home at his trial with great vehemence by William Prynne, was that he had countenanced 'the setting up of images in churches, church windows and other places of religious worship." "12 As a preacher, Donne himself consistently used conciliatory language, which showed sympathy for the restrained use of iconography, yet an equal (or greater) degree of caution towards it. For instance, Gilman notes a sermon preached in May of 1627, where Donne explains that images can have "sometimes a good, sometimes a bad sense in the Scriptures." He ends the same sermon with a warning regarding both extremes:

Vae idolatris, woe to such advancers of Images, as would throw down Christ, rather than his image: But Vae Iconoclastis too, woe to such peremptory abhorrers of Pictures, and to such uncharitable condemners of all those who admit any use of them, as had rather throw down a Church, then let a picture stand. ${ }^{13}$

Obviously, Donne's position here castigates the extremists of either stripe who would violate the fundamentals of Christianity for essentially partisan ends. However, Donald Friedman, in "Christ's Image and Likeness in Donne," argues that, as he neared the end of his life, Donne grew less comfortable with holy images, "advising King James in a sermon preached 
at court in 1629 that 'God . . . was the first, that made Images; and he was the first, that forbad them. He made them for imitation; he forbad them in danger of adoration." 14 It seems, therefore, that Donne's opinion approached moderate iconoclasm in later life. We must remember, too, that this happened as ecclesiastical power was increasingly placed in Laudian hands. Doerksen notes that, as of a year before Donne preached the abovementioned sermon, "Laud was his immediate superior as Bishop of London"; 15 the expedient course would have been at least to remain silent on the issue. Indeed, in Conforming To the Word, Doerksen writes that, in his last years, Donne distanced himself from Laud and his faction - to his own professional cost. ${ }^{16}$

Yet consider what Ernest Gilman calls the "intriguing if partial record in the bequest specified in [Donne's] will." 17 The will mentions numerous paintings of various types bequeathed to individuals and the church, "not a large collection by the standard of the long galleries then coming into fashion in great houses, but it was surely large enough to have filled nearly every corner of Donne's little world with imagery." 18 Gilman surveys the many contemporary portraits and Old Testament works mentioned in the will but also lists art that would have roused the ire of Beza or Zwingli:

A "Picture of the blessed Virgin Mary" hung in the "little Dining Chamber" and a "Picture of Mary Magdalen in my Chamber." . . Two paintings are noted as hanging in Donne's "Study." . . . Here Were a "B:Virgin and Joseph" and a "Picture of laying Christ in his Tomb.",

Gilman states, "Such quarters would have preserved more than a whiff of Roman piety." 20 It is possible that this collection shows that Donne was nurturing Papist sentiments, but when one considers the increasingly iconoclast stance articulated in his sermons (which, as we have seen, entailed a political risk by 1625), such a conclusion is unsatisfying.

Instead, I believe that Donne drew a firm distinction between public and private, where religious images were concerned. What could inspire dangerous "adoration" in a cathedral could still be useful and edifying in the private possession of a mature Christian. It is a position similar to that which, as Horton Davies writes, was affirmed by the Calvinist theologian William Perkins, who approved of the use of images in "sacred or profane books used in private." ${ }^{21}$ Of course, Donne's will lists actual paintings, not simply books of woodcut images. Nevertheless, I believe his art collection can be seen to extend the Calvinist practice of what Davies calls "domesticated" imagery. Davies states that Reformists "produced works for the council chamber or the home, but not for the house of God." 22 For Donne, the icon's values are recognised, and retained, but its idolatrous power — so potent in the 
numinous Laudian edifice - is nullified, since its context is changed. Ultimately, I am describing a shift from the ceremonial to the contemplative: the icon is no longer used in producing order, awe and ritual dignity (the Laudian aim); instead, its function is to aid in the reflection and devotion of the individual. ${ }^{23}$ I believe that this attitude towards iconography can be seen in Donne's religious poetry, where holy images are endorsed in the mind rather than on the wall.

Even in "The Cross," a relatively early devotional poem, this sentiment is emerging. Like Gregory the Great, ${ }^{24}$ Donne appreciated how a visual image could work for the viewer's personal spiritual benefit. "The Cross" is a response to the desire of Puritans to eliminate crosses from churches as symbols of Catholic idolatry, just as they had eliminated images of Christ and the saints. ${ }^{25}$ Donne's speaker argues that to abolish crosses is a futile endeavour:

Who can deny me power, and liberty

To stretch mine arms, and mine own cross to be?

Swim, and at every stroke, thou art thy cross,

The mast and yard make one, where seas do toss.

Look down, thou spiest out crosses in small things;

Look up, thou seest birds raised on crossed wings. (17-22)

Everywhere the speaker looks, nature replicates the "image of his cross" (2), thereby affirming the truth of the crucifixion. Certainly, it is a symbol accessible to literate and illiterate alike. The speaker decides that "Material crosses then, good physic be" (25) and resolves that "From me, no pulpit, nor misgrounded law, / Nor scandal taken, shall this Cross withdraw" (9-10). DiPasquale sums up the argument thus: "Looking away from the image of the cross implies a rejection of the Christian's duty to be crucified with Christ." 26

However, while "The Cross" is closer to the iconophile perspective than Donne's later verse, the poet does not simply endorse it. First, it should be emphasised that the crosses the speaker praises are natural ones - drawn from the private examination of nature - not iconic or liturgical ones (though the speaker's reason for pointing them out is the defence of iconic crosses, the "natural" ones he discusses depend on individual interpretation). Beyond this, however, the poem argues that, useful and prevalent as natural crosses are, it is "spiritual" crosses that "have chief dignity" (26). The speaker encourages him to "cross thyself in all. / Then doth the Cross of Christ work fruitfully / Within our hearts" (60-62). "That Cross's pictures" (63) which exist in the self are favoured over the external ones. So, the reader is told, 
Then are you to yourself, a crucifix. ...

Let crosses, so, take what hid Christ in thee,

And be his image, or not his, but he. (32-36)

The language is confusing, even for Donne, but what occurs is a spiritual collusion between the self and Christ. Gilman explains it as the "'spirituall' cross of therapeutic tribulation: its embrace . . virtually transforms its bearer into Christ himself, and so validates the image absolutely by closing the gap between it and its prototype." 27 Thus, though the external crosses are valid, they are "validated" only by the internal, which "cure much better" (28).

The seven-sonnet sequence "La Corona" affirms the same conclusion. Also an early devotional work, "La Corona" is made up of an introduction, followed by six vignettes in the story of Christ. Some consider this sequence to be highly Anglo-Catholic in nature: ${ }^{28}$ certainly the prevalence of and respect offered to Mary (to whom Christ is both "son, and brother" [II, 10]) support this view. Furthermore, the structure of the work, with an individual sonnet devoted to events like the Nativity and Crucifixion, seems squarely in the iconophile tradition. The sequence could be compared to a series of stained-glass windows or panel paintings, each depicting an important event in the life of Christ. Yet the language of the sonnets is much less descriptive than it is conceptual. In "Resurrection" we do not have a depiction of Christ's return from the dead, with such classic tropes as the stone rolled away, the empty tomb, or Jesus appearing to Mary Magdalene. Instead, the poem muses on how "life, by this death abled, shall control / Death, whom thy death slew" (5-6). Likewise, in "Annunciation," Mary is not described, nor is Gabriel, who "announces" the glad tidings. Rather, usurping the angel's role, the poet addresses Mary, speculating that "thou art now / Thy maker's maker, and thy father's mother" (11-12). This is not to say that such theological issues are unworthy of attention; Christianity is full of paradoxes that Donne continually contemplates in his poems. But in a sequence made up of specific events, it is striking that so little attention is paid to actually describing them.

"Temple" and "Ascension" both engage in brief, passing depictions (of the adolescent Jesus instructing the Temple rabbis, of the clouds parting), but it is in "Nativity" that we find Donne's most important reference to the act of seeing. However, it is not for the simple task of describing the scene. The speaker says, "See'st thou, my soul, with thy faith's eyes, how he / Which fills all places, yet none holds him doth lie" (9-10). The same process is at work here that we witnessed in "The Cross." A spiritual image is proffered instead of a physical one, and the reader is invited to look, not with 
actual, literal eyes, but with the eyes of the soul. The invitation is striking, considering the context - a series of poems that would seem to cater to the visual. The image of a tiny infant contrasted with the magnitude of space and time effectively illustrates the point of Christ's combined greatness and humility. It is a picture valuable for Christian enlightenment, but one seen internally. One is reminded of the spiritual "crown of glory, which doth flower always" (I, 8) and is preferred to the worldly "vile crown of frail bays" (5). The poet finds value only when the picture is painted within, through the process of active belief ("faith"); the external pictures are hardly worth mentioning.

"La Corona" raises an important issue in terms of sixteenth-and seventeenth-century religious art: namely, the emblem tradition. Emblem books arrived in England from the continent during the reign of Elizabeth I and, despite associations with Catholicism, were widely imitated and disseminated. Barbara Lewalski states that Protestants were "active in the field sometimes revising Catholic collections and sometimes devising new plates and books along somewhat different lines." 29 They are essentially "curious amalgams of picture, motto and poem." "30 The various parts are essential for total comprehension; Gilman says that "the text is implicated in the picture, the picture explicated in the text," a relationship that he compares to the Christian understanding of the Old and New Testaments. ${ }^{31}$ It is a highly allegorical form; one pertinent example is the emblem on the title page of the 1650 edition of Henry Vaughan's Silex Scintillans. It shows a stony heart (with a human face superimposed), which a heavenly arm is striking with a flint, producing both sparks and tears. It is accompanied by a Latin motto which praises the God who breaks "through the rocky barrier of my heart, and it is made flesh that was before a stone." 32 One likely reading is that the emblem signifies the painful but necessary process of the stony heart being broken by God's love. ${ }^{33}$ The purpose is ultimately rhetorical, ${ }^{34}$ with the reader/viewer forced to interpret and thereby internalise the emblem's message. In Sloane's explanation, "the symbols became actors in a visual allegory and their significance became psychological." 35 It is easy to see why such an image would be unproblematic for Calvinists. The very nature of an emblem is such that it reflects attention beyond itself toward the spiritual truth it signifies. An icon, the Puritans thought, did the opposite, drawing the viewer's attention to it, away from God. Thus, when Lewalski tries to resolve the seeming Catholicity of "La Corona" with the Protestant ethos she believes to be motivating Donne, she calls the work a poetic emblem: "Donne has created a sequence which is not so much meditation [Louis Martz's classic argument] as emblem, a crown of prayer and praise with some resemblance to those emblem figures of olive, bay and laurel 
wreaths." The circular form of the poem, whereby the last line of one sonnet is the first of the following and the beginning and end share the line, "Deign at my hands this crown of prayer and praise" $(\mathrm{I}, 1)$, makes it a crown of sorts that "conjoin[s] the two impulses of "prayer and praise." 36

Icons, as a rule, were both revered and vilified because of the spiritual aura associated with them. Emblems, on the other hand, were significant because of their allegorical and "psychological" effect on the spectator. It should also be stressed that emblems - disseminated in books, rather than on public walls - were an essentially private art form. This distinction is of prime importance in a late poem of Donne's, "A Hymn to Christ, at the Author's Last Going into Germany." In this poem, the two concepts of emblem and icon are interwoven in the first stanza and distinguishing them is crucial:

In what torn ship soever I embark,

That ship shall be my emblem of thy ark;

What sea soever swallow me, that flood

Shall be to me an emblem of thy blood;

Though thou with clouds of anger do disguise

Thy face; yet through that mask I know those eyes. (1-6)

Emblems, then, are employed as the speaker discusses using external things, the ship and the sea, to represent spiritual properties metaphorically. The ship, as emblem, will remind him of God's salvation of Noah. Yet the sea that might otherwise represent the ominous, deadly deluge is metaphorised differently. It becomes a New Testament symbol: Christ's saving blood. In the second stanza Donne elaborates: "When I have put our seas 'twixt them and me" he says of his loved ones, "Put thou thy sea betwixt my sins and thee" (11-12). It now becomes the gulf separating him from his corrupted past. The speaker has allegorised ship and sea so that both are comforting symbols of redemption, one from his possible physical death, the other from damnation.

I believe that the same transformation is occurring with the sky. In lines 5 and 6, the speaker discusses recognising God's face through the clouds. This seems to be, like the crosses examined earlier, an instance of seeing holy images in the natural world. But if one is conscious of the language, and the emblem-context, in the poem, one realises the same process is occurring here that occurred with the "ship" and the "sea." The sky has become an emblem for God's temperament - clear weather is equated with divine approval and clouds with anger. An intimidating storm at sea can then symbolically represent God's just wrath, which comforts the speaker because, although God's eyes may be temporarily "turned away" (7) in anger, 
"they never will despise" (8). There is a process of representation at work in the "Hymn" that sees spiritual comforts extrapolated from physical things when those things are regarded as allegorical emblems.

This is very different from arguing that Donne sees God's actual face imprinted in the sky and draws comfort from it, as if it were a giant Shroud of Turin. Rather, he associates one thing with another, as with the striking of the stony heart in Vaughan's emblem. In the poem's fourth and final stanza, Donne makes it clear that he was not discovering cosmic iconography by saying "Churches are best for prayer, that have least light: / To see God only, I go out of sight" (29). He is not, therefore, "seeing" God while above deck on the ship, staring into the sky, but rather drawing from the sky a truth about God's nature. To see God, he retires into a dark, intimate space. ${ }^{37}$ The paradox of seeing best where there is "least light" shows us that, as in "La Corona," it is "faith's eyes" that are really observing God. He concentrates on finding his image, not in the external world, but in his heart.

In "Upon the Annunciation and Passion Falling Upon One Day. 1608," the same distinction between emblem and icon needs to be made. Considering the sublime coincidence of both holy days, the speaker remarks,$$
\text { ... today }
$$

My soul eats twice, Christ hither and away.

She sees him man, so like God made in this,

That of them both a circle emblem is,

Whose first and last occur. (1-5)
}

Since the beginning and end of Christ's mortal existence are celebrated on the same day, a circle is used to emblematise his trajectory from the divine to the human and back again. Yet alongside the emblem (which helps to impress the importance of the coincidence upon his mind), Christ is seen by the soul in human form. Donne's soul continues to "see" the events of both fateful days:

She sees at once the virgin mother stay

Reclused at home, public at Golgotha.

Sad and rejoiced she's seen at once, and seen

At almost fifty, and at scarce fifteen.

At once a son is promised her, and gone,

Gabriel gives Christ to her, he her to John. (11-16)

These images are exactly the kind that iconophiles would erect in churches, and by witnessing scenes from Christ's conception and death the speaker apprehends that "Death and conception in mankind is one" (34). Here again, 
though, Donne is describing what he sees, not with the actual eye, but with the spiritual.

In "Good Friday, 1613. Riding Westward," it is the soul itself that becomes emblematised as a sphere "Subject to foreign motions" (4). Prompted by business to be travelling on the most sombre of days, the speaker has to admit to himself:

Yet dare I almost glad, I do not see

That spectacle of too much weight for me.

Who sees God's face, that is self life, must die;

What a death were it then to see God die? (15-18)

The image is powerful but terrifying: even Moses was allowed to glimpse God only from behind as he passed by. The pathos and brutality of the Crucifixion would be infinitely worse. The speaker goes into great visual detail, as he considers the terrible shock of seeing things like

... that blood which is

The seat of all our souls, if not of his,

Made dirt of dust, or that flesh which was worn,

By God for his apparel, ragged and torn. (25-28)

There is a marked sense of unwarranted presumption and great psychological trauma associated with seeing the saving blood mixed with earth and churned to mud. Viewing the Passion is something the speaker does not feel worthy of, and, instead, he desires God's "Corrections" to improve him (38). All this time, though, he has been viewing the Passion, as he reconstructs it mentally. He makes this explicit, saying, "Though these things, as I ride, be from mine eye, / They are present yet unto my memory, / For that looks towards them" (33-35). What he cannot witness physically can be of great help when witnessed mentally - yet another comment on the proper place of holy icons. Granted, there is an important distinction to be made between viewing artistic images of the Crucifixion and the Crucifixion itself. But the critical difference is once again between seeing things outside the self and seeing things inwardly. The speaker feels unworthy to witness the spectacle of the Crucifixion anywhere but in his mind; there, it can be helpful. He closes the poem by begging God, "Restore thine image, so much, by thy grace, / That thou mayst know me, and I'll turn my face" (41-42). The image is not condemned; it is made to sound almost central to his salvation. Yet it is a private image viewable only by him and God. Before he can turn back to the east, metaphorically equated with the actual image of the passion, the picture inside the speaker must be perfected. When he begs God to "Burn off my rusts, and my deformity" (40), he is asking, in part, for the internal 
image he has of Christ to be perfected: then he will be worthy to behold with the physical eye.

Most readers consider the "Holy Sonnets" to stand at the centre of Donne's devotional verse, and I believe two of the "Sonnets" comment directly on the iconoclast controversy. First, I wish to examine Holy Sonnet 18, "Show me dear Christ." As in Satire 3, the speaker desires to know where in the confessional confusion the true bride of Christ can be found. He begins by asking:

Show me dear Christ, thy spouse, so bright and clear.

What, is it she, which on the other shore

Goes richly painted? Or which robbed and tore

Laments and mourns in Germany and here? (1-4)

The lines beg the obvious question: if she's "bright and clear," why can he not see her? The two alternatives presented are clearly the heavily adorned Roman church (an interesting emotional shift from the "rags" she wore in Satire 3) and the sparsely decorated Protestant. Neither description is particularly flattering, and Gilman states that "The unhappy choice seems to be between two spouses chaste in neither case, the one flaunting herself, all too eager to be shown, the other no less exposed, as if the iconoclasm of the Reformation were itself a kind of sexual tampering." 38 Both are described with highly visual imagery, but neither approaches the "bright and clear" ideal.

The poem's erotic connotations are heightened in the final four lines, when, after speculating on how to find her, the speaker begs Christ:

Betray, kind husband thy spouse to our sights,

And let mine amorous soul court thy mild dove,

Who is most true, and pleasing to thee, then

When she's embraced and open to most men. (11-14)

Expressed in the lines is a very natural desire to know which church is the "most true," as well as a desire for religious tolerance (that the most charitable, accessible confession be adopted). Yet why should the speaker court the church? It is one thing to desire alignment with the proper church, but should he not desire to court Christ rather than Christ's spouse? Gilman also points out that

the lusty snicker in the word "open" marks the difference between Christ's true church - universal, welcoming, open to the embrace of faith — and the speaker's demand for a vision of that church pleasing to him. . . The poem thus evokes the urgency of the speaker's desire while it reveals the idolatrous, and adulterous, contamination of that desire to "make love" to the image it seeks." 
R. V. Young, in Doctrine and Devotion, sees the same connotations, but moderates them by saying that "Donne writes metaphorically, not literally: sexual 'grace' is a metaphor for grace — the ineffable, inconceivable gift. ... The 'shocking' metaphor is intended to startle us into recognition of how very different God's love is from our own." 40 It is an argument I find quite convincing (for one thing it seems supported by the generally devout timbre of the "Holy Sonnets" as a group). Yet whether or not one goes as far as Gilman in seeing "adulterous" desire in the sonnet, there is clearly a question of misplaced desire, which hinges on the question of imagery. By trying to discern which church is the correct one with the eye, by making the apparel of the "bride" (lavish or humble) the first consideration, the speaker has confused the proper object of affection. The physical presence (or absence, for that matter) of holy images is not the correct criterion for evaluation.

I feel that in Holy Sonnet 13 Donne re-affirms his conviction that the proper place for images is in the self. Of all Donne's poetry, "What If This Present" is the work most pertinent for this discussion of religious imagery. To understand it properly, however, it helps to be familiar with one of the elegies written by Donne as a young (and likely still-sceptical) Protestant convert - the same young man who had written Satire 3. In Elegy 10, "The Dream," the speaker discusses keeping the beloved's picture in his heart. It would be negligent to read this poem without acknowledging the religious context it so obviously references, and it would be equally erroneous to read "What If This Present" without acknowledging the Elegy as an intertext. In Elegy 10 the speaker begins:

Image of her whom I love, more than she,

Whose fair impression in my faithful heart,

Makes me her medal, and makes her love to me,

As kings do coins, to which their stamps impart

The value: go, and take my heart from hence. (1-5)

It is a rare love poem that admits to valuing the mental (though admittedly idealised) image of the beloved more than the beloved herself. However, the poem's attitude toward that image is deeply ambivalent. By stamping this image upon his heart, the woman gives value to it, just as a gold coin is given its particular value by the portrait of a monarch. Yet the value the speaker accords the image makes it ominously powerful. The woman's image makes the heart a thing too precious for the owner to possess: "too great and good for me" (6). His mind is not powerful enough to digest it, as "Honours oppress weak spirits, and our sense / Strong objects dull; the more, the less we see" (7-8). The mistress must therefore take it, and his "reason" with it. ${ }^{41} \mathrm{He}$ begs at the end of the poem for the "dearest heart, and dearer image" 
(21) to stay, that he may grow "Mad with much heart," rather than "idiot with none" (26). Essentially, the poem parallels Donne's argument about holy images, stressing the benefits and dangers of a picture's transcendent power. To be sure, this is a mischievous poem, which toys with concepts that others took very seriously (and Donne himself would later take seriously as well). Nevertheless, the speaker plays with the arguments of both iconoclasts and iconophiles, even as he flatters the woman.

I am convinced that the poem and its conceit of a face imprinted on a heart were clearly in Donne's thoughts as he wrote Holy Sonnet 13. Considering the sobering possibility, "What if this present were the world's last night?", the speaker addresses the poem to his soul:

Mark in my heart, O soul, where thou dost dwell,

The picture of Christ crucified, and tell

Whether that countenance can thee affright,

Tears in his eyes quench the amazing light,

Blood fills his frowns, which from his pierced head fell,

And can that tongue adjudge thee unto hell,

Which prayed forgiveness for his foes' fierce spite?

No, no. (2-9)

The affirmation of Christ's mercy comes from contemplating an image of Christ found, not in a stained-glass window, but in the heart, where formerly his mistresses' faces were viewed. Just as Donne's own chambers were filled with images he did not recommend for public use, so does his heart, the dwelling place of the soul, have its own icon. Moreover, it is the particular character of the image that gives him comfort: he does not see a sombre, Byzantine Christ wearing a stern expression of judgment. Instead, he sees tears which "quench" the otherwise harsh light of the divine gaze.

The comparison Donne draws in the third quatrain and couplet, however, makes this poem one of the most problematic in his corpus:

... but as in my idolatry

I said to all my profane mistresses,

Beauty, of pity, foulness only is

A sign of rigour: so I say to thee,

To wicked spirits are horrid shapes assigned,

This beauteous form assures a piteous mind. (9-14)

Not only is Christ compared to the speaker's former lovers but also, in a grand generalisation, the unattractive woman is frigid and unyielding, the beautiful naturally willing. For a modern reader, such a sentiment might be 
disconcerting in a love poem; to apply the argument to God's mercy has been called "monstrous," "blasphemous" and "sophistry." 42 Gilman, for example, sees this as "an attempt to seduce Christ into granting an assurance of mercy." 43 To him the equation is proof that "idolatry" of a new kind is present in the speaker. He believes that Donne is writing from a solidly iconoclast position and that the next sonnet, "Batter my heart, three-personed God," is the grand act of iconoclasm that will rid the metaphorical chapel of its forbidden images, "the one poem shattering a devotional image that the other had set up." 44

This is an interesting argument, but, apart from the fact that it rests on the unknowable "intended" sequence of the sonnets, I believe that "What If This Present?" is innocent of the charges levelled against it. In a sermon given in 1624, Donne asserts, "God set upon us all, his Image in our soules, at our making, his Image, that is his Sonne, upon our bodies and soules, in his incarnation." 45 The statement counters Gilman's notion that an act of iconoclasm is required to purge the self of idolatrous images; clearly, in Donne's theology, the face of Christ is very properly "set upon us all." Furthermore, Young states that, in Calvinist doctrine, the elect's assurance of redemption hinges on the expression the image wears: "interpretation of the 'picture' in the persona's heart — is it a 'marke' of election or condemnation? - is contingent upon the speaker's emotional response to Christ's countenance." 46

Thus, for Donne to be attuned to the image's appearance is natural and proper. Also, recognising the beauty of the face, in Young's view, "requires the grace of charity," since, as he perceptively points out, "To find such a tearful, bloody visage 'beauteous' is not an obviously natural or spontaneous response." 47 To draw the same conclusion with the "profane mistresses" was a mistake. There, the beauty was only physical, and worshipping it led to what Donne properly defined as "idolatry." We know from Elegy 10 that he is not being casually hyperbolic in using the word, since there he rejoiced in growing dangerously excessive in cherishing the woman's image. However, in Holy Sonnet 13, as Friedman notes, "What has changed is the definition of beauty," as well as the object of veneration. ${ }^{48}$ The sonneteer, who searches unsuccessfully for the true revelation of Christ in Holy Sonnet 18 , finds it in 13. In the former, he had been preoccupied with externals, in seeing with the eye. In the latter, he has turned his gaze from public icons (or the lack thereof) to the image in his own heart.

Interestingly, Donne amalgamates ideas from both Elegy 10 and Holy Sonnet 13 in "To Mr. Tilman After He Had Taken Orders." There, he discusses the change that occurs after Tilman's spiritual awakening: 
38 / Renaissance and Reformation / Renaissance et Réforme

Art thou the same materials, as before, Only the stamp is changed; but no more? And as new crowned kings alter the face, But not the money's substance; so hath grace Changed only God's old image by creation,

To Christ's new stamp, at this thy coronation? (13-8)

The coin metaphor is redeemed, as Donne uses it to explain his friend's conversion: he is the same man, but a new monarch now reigns. The "new stamp" of Christ replaces the wrathful image of the Old Testament God. Like the speaker of Holy Sonnet 13, Tilman can draw comfort from the merciful face of Christ newly imprinted on his soul.

It is an intriguing paradox of Donne's poetry that a writer so little given to visual descriptions could be so fascinated by the act of seeing. In "The Ecstasy," he describes how "Our eye-beams twisted, and did thread / Our eyes, upon one double string" (7-8). In "The Good Morrow," he discusses the tiny images each lover's face imprints on the other's eye: "My face in thine eye, thine in mine appears" (15), while in "Witchcraft By a Picture," he elaborates the same conceit, though this time the picture is "drowned in a transparent tear" (3). Unlike so many of the love poets popular in his era, he is uninterested in the colour of his mistress's hair or cheeks, and yet he tells us in Elegy 10 that the woman's image is more valuable than the woman herself. However, in both his love poetry and his devotional poetry, the physical is never of great importance to Donne. In "The Undertaking" he will write of erotic attraction:

But he who loveliness within

Hath found, all outward loathes,

For he who colour loves, and skin,

Loves but their oldest clothes. (13-17)

The statement is very like one that a much different John Donne would make to his friend Tilman years later, in a poem about divine love:

Alas poor joys, but poorer men, whose trust

Seems richly placed in refined dust;

(For, such are clothes and beauty, which though gay,

Are, at the best, but as sublimed clay.) ("To His Friend,"

31-34)

In both poems there is a powerful sense that what is outside is insufficient. The image in Elegy 10 is not one found in nature, but only in Donne's heart, where he will later place the image of Christ. Seeing is important to Donne, 
but it is no exaggeration to say that words are insufficient to describe what he sees. Whether the subject is God or the speaker's mistress, it is always that private image, seen only by himself, that has any lasting value.

Ultimately, Donne's attitude to religious imagery is a tolerant one: he acknowledges the real value a visual image can have in promoting understanding and religious growth; certainly, in poems like "The Cross," he refuses to endorse the iconoclasm desired by extremists. However, he refrains from advocating public iconography, believing that the thing that makes it useful can also make it spiritually dangerous. Instead, he attempts to preserve the positive while rejecting the negative. Writing about Donne's basing of works like "A Hymn to God the Father" and "A Litany" on aspects of the church service, Lewalski writes: "These poems alike are remarkable in that they transpose public forms into private devotions relating directly to the personal situation and experience of the speaker." 49 By relocating the holy icon in the self, Donne is doing the same thing: he modifies what was a public form for his private use, appreciating its relevance to his own spiritual life while nullifying its idolatrous potential.

\section{McGill University}

\section{Notes}

1. I would like to thank my M.A. supervisor, Dr. Ronald Huebert of the Dalhousie University English Department, for his assistance and encouragement in this project.

2. John Phillips, The Reformation of Images: Destruction of Art in England, 1535-1660 (Berkeley: University of California Press, 1973), p. 3.

3. All verse quotations are from John Donne, The Complete English Poems, ed. A. J. Smith, rev. ed. (London: Penguin Books, 1996); line numbers cited parenthetically within the text refer to this edition.

4. To be sure, in his portrait of young men, the open-minded Gracchus, who "loves all as one" (65) is also criticised. However, while Gracchus may be somewhat naïve (or even indifferent), the general tenor of the poem, which argues that he who would ascend the hill of Truth "about must and about must go" (81), privileges a moderate position over any other.

5. Ernest B. Gilman, Iconoclasm and Poetry in the English Reformation: Down Went Dagon (Chicago: University of Chicago Press, 1986), p. 118.

6. Kenneth Fincham, Introduction, The Early Stuart Church, 1603-1642, ed. Kenneth Fincham (London: Macmillan, 1993), pp. 6-8. This view is contrary to the one dominant since the nineteenth century, which held that a peaceful Arminian consensus was upset by the discontented Puritans during the reign of Charles I. Increasingly, though, scholars are agreeing with Fincham. Julian Davies, in The Caroline Captivity of the Church: Charles I and the Remoulding of Anglicanism, 1625-1641 (Oxford: Clarendon Press, 1992), claims that Charles, a staunch Arminian, facilitated the doctrinal and liturgical program of the Laudians and upset the careful Calvinist consensus of his father and Elizabeth Tudor: "the Caroline church represented not the 
40 / Renaissance and Reformation / Renaissance et Réforme

apogee of Anglicanism, but a very weird aberration from the first hundred years of the early reformed Church of England" (p. 3). Peter Lake, in an essay on the Laudian approach to ceremony and decor agrees, pointing out that many of the central tenets of the Laudian view flew in the face "of conventional Jacobean Protestant wisdom. Even to quite moderate divines raised within what we might term the English Reformed tradition, many features of Laudianism appeared at best worrying and at worst frankly Popish" ("The Laudian Style: Order, Uniformity and the Pursuit of the Beauty of Holiness in the 1630s," in Fincham, ed., p.181).

7. Theresa M. DiPasquale, Literature and Sacrament: The Sacred and the Secular in John Donne (Pittsburgh, PA: Duquesne University Press, 1999), p. 2.

8. Daniel W. Doerksen, "Preaching Pastor Versus Custodian of Order: Donne, Andrewes, and the Jacobean Church," Philological Quarterly 73 (1994): 418.

9. Ibid., pp. 418-19.

10. Ibid., p. 423.

11. Gene Edward Veith, Jr., Reformation Spirituality: The Religion of George Herbert (Lewisburg, PA: Bucknell University Press, 1985), p. 179, citing The Sermons of John Donne, ed. George R. Potter and Evelyn M. Simpson, 10 vols. (Berkeley: University of California Press, 1953-62), 8: 228.

12. Gilman, Iconoclasm and Poetry, p. 9.

13. Potter and Simpson, eds., 7: 433.

14. Donald M. Friedman, "Christ's Image and Likeness In Donne," John Donne Journal 15 (1996): 82, citing Potter and Simpson, eds., 9: 75. Of course, by the time of this sermon Charles (not James), had been king for four years. Given Charles's devotion to the high-church cause, Donne's distaste for icons must have been very strong for him to preach such a sermon.

15. Doerksen, "Preaching Pastor," p. 418.

16. Daniel W. Doerksen, Conforming to the Word: Herbert, Donne, and the English Church before Laud (Lewisburg, PA: Bucknell University Press, 1997), pp. 23-24.

17. Gilman, “To Adore or Scorn an Image,” p. 67.

18. Ibid., p. 68.

19. Ibid., p. 71.

20. Ibid.

21. Horton Davies, Worship and Theology in England: From Andrewes to Baxter and Fox, 1603-1690 (Princeton, NJ: Princeton University Press, 1975), p. 201.

22. Ibid., p. 207.

23. It is interesting that Donne's practice as regards iconography is very similar to James I's. Phillips writes:

James I himself claimed not to be an iconoclast; he followed Henry VIII's distinctions concerning images by accepting their commemorative nature and rejecting those representations which were worshipped or associated with any holiness ("abused"). . . . James I revealed a marked contrast between public statement and private practice. Desiring "comeliness," the King gave instructions in 1617 for the royal chapel at Holyrood to be decorated with gilded figures of 
David K. Anderson / John Donne and the English Iconoclast Controversy / 41

apostles and patriarchs. When the Scottish bishops complained, the king yielded.

(p. 141)

Though the king's actions were perhaps hypocritical in a way that Donne's were not, the two conformist Calvinists strike a similar balance between public and private.

24. Gilman, Iconoclasm and Poetry, p. 32.

25. Barbara Kiefer Lewalski, Protestant Poetics and the Seventeenth-Century Religious Lyric (Princeton, NJ: Princeton University Press, 1979), p. 255. DiPasquale points out that the poem's argument is equally aimed at the controversy concerning ritual crossing during the baptismal ceremony (p. 31). Very much to the point is David Cressy's quotation of the "Jacobean Presbyterian" David Calderwood, who draws a parallel between crossing and iconography: "Admit once the aerial cross in baptism . . . [and] ye cannot refuse to set up the material cross and the rood in the kirk, nor the wooden or stone crosses in the highways" (David Cressy, Birth, Marriage, and Death: Ritual, Religion and the Life-cycle in Tudor and Stuart England, [Oxford: Oxford University Press, 1997], p. 126). The two issues are clearly inseparable.

26. DiPasquale, Literature and Sacrament, p. 35.

27. Gilman, “To Adore or Scorn an Image," p. 89.

28. Ibid., p. 71.

29. Lewalski, p. 185.

30. Ibid., p. 179.

31. Gilman, Iconoclasm and Poetry, p. 17.

32. As translated by Madeline Forey in her article, "Poetry As Apocalypse: Henry Vaughan's Silex Scintillans," Seventeenth Century 11 (1996): 163.

33. Michael Rothberg, "An Emblematic Ideology: Images and Additions In Two Editions of Henry Vaughan's Silex Scintillans," English Literary Renaissance 22 (1992): 87, argues that the removal of the emblem in the 1655 edition of Silex is an iconoclastic gesture and must be read as an ironic political statement directed at Puritan hegemony. Though Rothberg helpfully points out that the major emblematist Quarles was an ardent Royalist and Laudian (p. 91), I do not think that he properly acknowledges the very real esteem that Calvinists had for devotional emblems: they would, in my opinion, have been far more upset with Vaughan's poems than with his original title page, especially as the emblem is a clear allusion to Ezekiel 11:19.

34. Lewalski, p. 180.

35. Mary C. Sloane, "Emblem and Meditation: Some Parallels in John Donne's Imagery," South Atlantic Bulletin 39 (1974): 75.

36. Lewalski, p. 258.

37. It is worth noting that iconoclasts agitated against using (excessive) candles in church, feeling that Catholic candle lighting verged on idolatry.

38. Gilman, Iconoclasm and Poetry, p. 174. There is an argument to be made, however, that in the case of the "robbed and tore" Protestant church, the "sexual tampering" was done by people other than iconoclasts (especially when we consider that "Germany" could connote Lutherans as well as Calvinists). Smith, in the notes to his edition, cites Helen Gardner's assumption that the reference is to "the collapse of the Protestant cause in Bohemia after the defeat of the Elector of Hanover. . . English interests were deeply 
42 / Renaissance and Reformation / Renaissance et Réforme

involved in the Elector's cause and there was general dismay here at his defeat" (p. 636).

39. Gilman, “To Adore or Scorn an Image," p. 85.

40. Robert V. Young, Doctrine and Devotion in Seventeenth-Century Poetry: Studies in Donne, Herbert, Crashaw, and Vaughan (Cambridge: D. S. Brewer, 2000), p. 30.

41. Smith reminds us that the heart was considered the seat of reason (Smith, ed., p. 426).

42. Friedman, p. 75.

43. Gilman, "To Adore or Scorn an Image," p. 91.

44. Ibid., pp. 91-92.

45. Potter and Simpson, eds., 6: 160.

46. Young, p. 25.

47. Ibid.

48. Friedman, p. 91.

49. Lewalski, p. 260. 